\title{
The Response of Wheat with Different Allele Statuses of the Gpc-B1 Gene under Zinc Deficiency
}

\author{
Natalia Kaznina ${ }^{1, *}$, Nadezhda Dubovets ${ }^{2}$, Yuliya Batova ${ }^{1}$, Anna Ignatenko ${ }^{1}$, Olga Orlovskaya ${ }^{2}$ \\ and Natalia Repkina ${ }^{1}$ (D) \\ 1 Institute of Biology of the Karelian Research Centre of the Russian Academy of Sciences, \\ 185910 Petrozavodsk, Russia; batova@krc.karelia.ru (Y.B.); angelina911@ya.ru (A.I.); nrt9@ya.ru (N.R.) \\ 2 Institute of Genetics and Cytology of the National Academy of Sciences of Belarus, 220072 Minsk, Belarus; \\ n.i.dubovets@igc.by (N.D.); O.Orlovskaya@igc.by (O.O.) \\ * Correspondence: kaznina@krc.karelia.ru
}

Citation: Kaznina, N.; Dubovets, N.; Batova, Y.; Ignatenko, A.; Orlovskaya, O.; Repkina, N. The Response of Wheat with Different Allele Statuses of the Gpc-B1 Gene under Zinc Deficiency. Agronomy 2021, 11, 1057. https://doi.org/10.3390/ agronomy 11061057

Academic Editor: Alessio Aprile

Received: 15 April 2021

Accepted: 20 May 2021

Published: 25 May 2021

Publisher's Note: MDPI stays neutral with regard to jurisdictional claims in published maps and institutional affiliations.

Copyright: (c) 2021 by the authors. Licensee MDPI, Basel, Switzerland. This article is an open access article distributed under the terms and conditions of the Creative Commons Attribution (CC BY) license (https:// creativecommons.org/licenses/by/ $4.0 /)$.

\begin{abstract}
The aim of this study was to investigate the effect of zinc ( $\mathrm{Zn})$ deficiency on the growth and grain yield of wheat with different allele statuses of the Gpc-B1 gene. For this research, common wild emmer wheat (Triticum turgidum ssp. dicoccoides (Koern. ex Asch. \&Graebn.) Schweinf.), bread wheat (Triticum aestivum L. cv. Festivalnaya), and two intogressive lines were used. T. dicoccoides and introgressive line 15-7-1 carry a functional allele of the Gpc-B1 gene, while the T. aestivum cv. Festivalnaya and introgressive line 15-7-2 carry the non-functional Gpc-B1 allele. Zn deficiency did not affect the shoot height or fresh weight of any of the studied plants. The only exception was $T$. dicoccoides, where a small decrease in shoot height was registered. Additionally, under Zn deficiency T. dicoccoides had an increase in flag leaf area, spike length, and dry weight, as well as in grain number and grain yield per spike. The other variants did not experience changes in the above-described parameters under Zn deficiency. Under Zn deficiency, the Zn concentration in the grains was higher in the plants with a functional allele of the Gpc-B1 gene compared to the plants with a non-functional allele. These results show that wheat with a functional allele of the Gpc-B1 gene growing under $\mathrm{Zn}$ deficiency is capable of grain production with a sufficient $\mathrm{Zn}$ concentration without a decrease in yield.
\end{abstract}

Keywords: wild emmer; wheat; zinc; Gpc-B1; growth; grain yield

\section{Introduction}

Zinc $(\mathrm{Zn})$ is an essential micronutrient for all organisms, with key catalytic and structural functions [1-3]. Zn is involved in numerous aspects of cellular metabolism [4,5]. Redox-inert metal ions such as $\mathrm{Zn}$ are key structural components of a large number of proteins [6]. Among the structural domains of proteins, $\mathrm{Zn}$ finger domains have a major physiological relevance [1,7,8]. In addition to this, the role of $\mathrm{Zn}$ in membrane integrity and stabilization, in the alleviation of oxidative stress, and as an intracellular second messenger has also been reported [9]. Zn regulates transcription directly through effects on DNA/RNA binding, and through site-specific modifications, regulation of chromatin structure, RNA metabolism, and protein-protein interactions [10]. Zn has a key role in autophagy regulation [11]. As $\mathrm{Zn}$ is essential for proliferative cells, its role in the regulation of immune cells is crucial ( $\mathrm{Zn}$ ions function as chemo-attractants for some immune cells and affect the maturation of dendritic cells and the development and function of T cells, etc.) [12]. Assessments made by the World Health Organization (WHO) concluded that approximately $50 \%$ of the world's population has suboptimal zinc nutrition [13]. Disbalances with regard to $\mathrm{Zn}$ deficiency as well as $\mathrm{Zn}$ excess are linked to a large number of illnesses, particularly immune diseases $[14,15]$. According to the International Zinc Nutrition Consultative Group, the national prevalence of zinc deficiency is high in South Asia, most of sub-Saharan Africa, and parts of Central and South 
America [16]. An estimated $17.3 \%$ of people worldwide are at risk of inadequate $\mathrm{Zn}$ intake, and $\mathrm{Zn}$ deficiency causes a loss of appetite, anemia, growth retardation, hypogonadism, and depressed mental function, etc. $[17,18]$. Therefore, it is crucial to develop effective measures to mitigate Zn deficiency.

Wheat, rice, and maize are the most important cereal crops across the world. Cereals constitute the largest source of calories in developed and developed countries. Some estimates suggest that wheat alone makes up $20 \%$ of the food calories and daily proteins consumed by 4.5 billion people [19]. Global wheat production in 2021 increased to 780 million tons [20].

To mitigate $\mathrm{Zn}$ malnutrition in developed countries, supplementation and food fortification are the main strategies. However, these strategies are difficult to put into effect in developing countries, taking into consideration the economic and social conditions. In this case, the increase in $\mathrm{Zn}$ concentration in wheat grain and the edible parts of other cereal crops through agronomic intervention or genetic selection is a strategy to mitigate micronutrient malnutrition. Some authors have proposed using some parental species of cultivated wheat (crop wild relatives) such as Aegilops ventricosa Tausch (which naturally has high zinc concentrations) for breeding and crossing with cultivated wheat or for direct cultivation as a source of zinc [21,22]. Current agriculture practices can improve the micronutrient content of foods through correcting soil quality, seed quality, and plant breeding (by means of a classical selection process or genetic modification) [23]. Genetic biofortification in volving classical breeding, gene discovery, and marker-assisted breeding approaches is a strategy to produce crops with higher micronutrient levels [24]. Previously, it was found that the Gpc-B1 gene, encoding the NAC (NAM, ATAF, CUC) transcription factor, wasinvolved in the regulation of $\mathrm{Zn}$ content in plants $[25,26]$. The presence of a functional allele of the Gpc-B1 gene is typical for wild-type tetraploid wheat (Triticum turgidum ssp. dicoccoides (Koern. ex Asch. \& Graebn.) Schweinf.), while most of the created tetraploid and hexaploid varieties of wheat have a non-functional copy of this gene or a deletion of this locus $[25,27]$. The use of the distant hybridization method makes it possible to breed wheat lines containing a functional allele of this gene. As a result, these lines are characterized by a higher content of proteins and trace elements in grain, including $\mathrm{Zn}[25,28]$. Moreover, the Gpc-B1 gene is involved in the control of the aging process of plants [26]. The aging of leaves, especially the sub-flag and flag leaves, makes the provision for the remobilization of essential micronutrients from the leaves into the spike. The regulation of this process is crucial for enhancing the supply of $\mathrm{Zn}$ into developing grains. There are fragmentary available data on the reaction of wheat with a functional allele of the Gpc-B1 gene to $\mathrm{Zn}$ deficiency. Therefore, the present study was conducted to investigate the effect of $\mathrm{Zn}$ deficiency on the growth parameters and grain production of wheat with different $G p c-B 1$ allele statuses.

\section{Materials and Methods}

\subsection{Plant Material}

Seeds of wild emmer wheat (Triticum turgidum ssp. dicoccoides (Koern. ex Asch. \& Graebn.) Schweinf.), common wheat (Triticum aestivum L. cv. Festivalnaya) and 2 introgressive lines (15-7-1 and 15-7-2) were received from the Institute of Genetics and Cytology of the National Academy of Sciences of Belarus in Minsk. Introgressive lines were created by crossing of T. aestivum cv. Festivalnaya and T. dicoccoides. Allelic status of the Gpc-B1 gene was determinated using codominant marker Xuhw89 [29]. Functionally active alleles of the Gpc-B1 gene were identified in T. diccocoides and introgressive line 15-7-1, whereas T. aestivum cv. Festivalnaya and line 15-7-2 had non-functional alleles. The non-functional allelic variant is characterized by the presence of a $1 \mathrm{bp}$ insertion within the coding region, resulting in a frame shift mutation that introduces a stop codon. The protein calculated for this allele is inactive. 


\subsection{Growth Conditions}

The experiment was conducted in greenhouse conditions during the wheat-growing season at the Agricultural Experiment Station belonging to the Karelian Research Centre $\left(61^{\circ} 45^{\prime} 6^{\prime \prime} \mathrm{N}, 119^{\circ} 25^{\prime} 10.9^{\prime \prime}\right.$ E) (WGS84), Petrozavodsk, Republic of Karelia, Russia. Wheat seeds were sown in pots (height $40 \mathrm{~cm}$, diameter $20 \mathrm{~cm}$ ) containing $5 \mathrm{~kg}$ of sand and 12 seeds per pot. Half of the pots were irrigated by Hoagland solution with micronutrient addition including optimal $\mathrm{Zn}(2 \mu \mathrm{M})(\mathrm{Zn}+$, control), and the other pots were irrigated by solution with micronutrients excluding $\mathrm{Zn}$ salt addition $(\mathrm{Zn}-, \mathrm{Zn}$ deficiency). Plants were harvested and analyzed at the seed-filling stage.

\subsection{Biometric Measurements}

The following morphological parameters and biometric measurements were obtained: main shoot height and shoot fresh weight (FW), flag leaf area, spike length and spike dry weight (DW), number of grains per spike, and grain yield per spike.

Leaf area was calculated as: $S=2 / 3 l d$, where $l$ is the length and $d$ is the width of the leaf [30].

FW was measured immediately after harvest. Spike and grain DWs were obtained after oven drying at $60^{\circ} \mathrm{C}$ until constant mass.

\subsection{Chemical Analysis}

The $\mathrm{Zn}$ concentration in grain was expressed as mg per $\mathrm{kg}$ DW and was analyzed by atomic absorption spectroscopy (AA-7000 Shimadzu, Japan) after prior mineralization in a solution of $\mathrm{HNO}_{3}$ and $\mathrm{HCl}(9: 1 \mathrm{v} / v)$ using Speedwave Digestion (Berghof, Eningen, Germany). Experiments were carried out using the equipment of the Core Facility of the Karelian Research Center of the Russian Academy of Sciences.

\subsection{Statistical Analyses}

For measurement of each parameter, 20 plants were taken. The data were processed using Excel 2007 (Micosoft, Redmond, WA, USA). Data were analyzed by ANOVA. The Student's $t$-test was used to compare means. Differences at $p<0.05$ were considered as statistically significant.

\section{Results}

\subsection{Effect of Zn Deficiency on Plant Growth}

Zn deficiency did not affect the shoot height and FW of all variants of wheat plants, with the exception of $T$. dicoccoides which had a decreased shoot height compared to the control (Table 1).

Table 1. The effect of Zn deficiency on shoot height and FW of wheat with different allelic statuses of the $G p c-B 1$ gene. Averages followed by different letters within the same parameter indicate statistically significant differences according to the $t$-test $(p<0.05)$. The data are expressed as means $\pm \mathrm{SE}$ $(n=20)$.

\begin{tabular}{ccccc}
\hline \multirow{2}{*}{ Variant } & \multicolumn{2}{c}{ Shoot Height $(\mathbf{c m})$} & \multicolumn{2}{c}{ Shoot FW (g) } \\
\cline { 2 - 5 } & Zn+ & Zn - & Zn+ & Zn- \\
\hline Triticum dicoccoides & $101.5 \pm 1.98 \mathrm{~b}$ & $95.55 \pm 1.77 \mathrm{c}$ & $2.38 \pm 0.17 \mathrm{c}$ & $2.60 \pm 0.17 \mathrm{c}$ \\
Triticum aestivum & $87.42 \pm 2.58 \mathrm{de}$ & $81.85 \pm 2.31 \mathrm{e}$ & $5.36 \pm 0.27 \mathrm{ab}$ & $5.06 \pm 0.18 \mathrm{~b}$ \\
cv. Festivalnaya & $99.85 \pm 3.78 \mathrm{bc}$ & $94.05 \pm 3.59 \mathrm{~cd}$ & $6.07 \pm 0.46 \mathrm{a}$ & $5.87 \pm 0.41 \mathrm{ab}$ \\
Line 15-7-1 & $114.26 \pm 3.33 \mathrm{a}$ & $114.45 \pm 2.54 \mathrm{a}$ & $4.97 \pm 0.27 \mathrm{~b}$ & $4.84 \pm 0.26 \mathrm{~b}$ \\
Line 15-7-2 & & &
\end{tabular}

At the same time, only in $T$. dicoccoides was the flag leaf area increased under zinc deficiency. The other variants had no differences in this parameter under Zn deficiency or its optimum amount (Figure 1). 


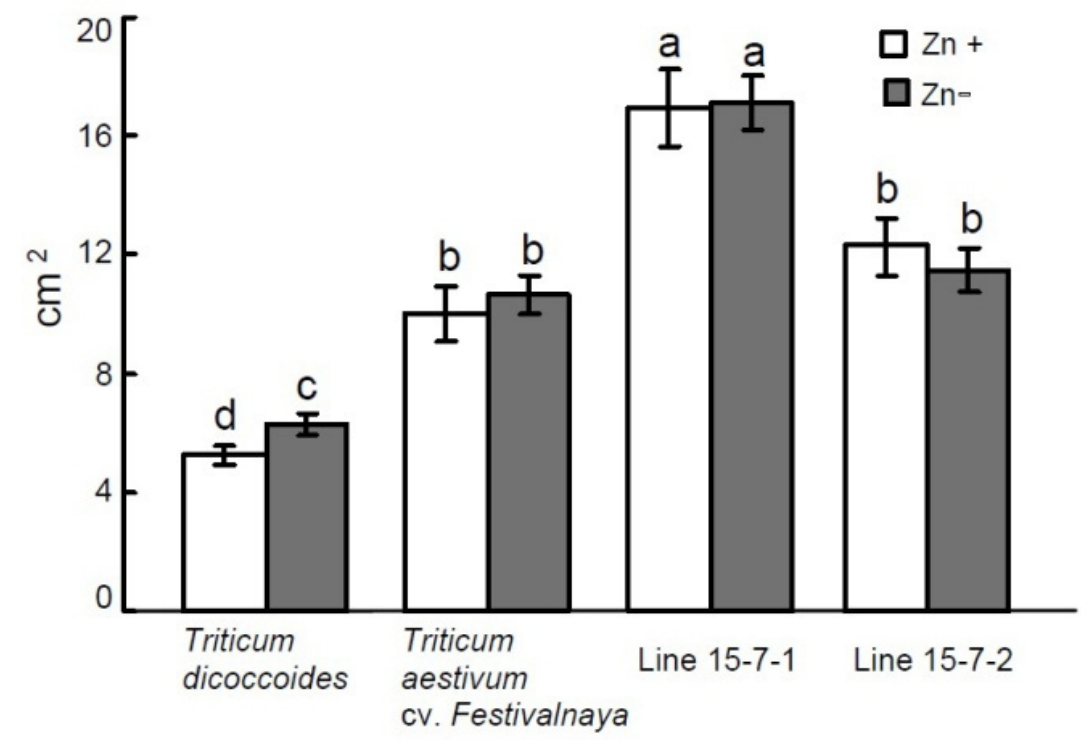

Figure 1. The effect of $\mathrm{Zn}$ deficiency on the flag leaf area $\left(\mathrm{cm}^{2}\right)$ of wheat with different allelic statuses of the Gpc-B1 gene.Averages followed by different letters within the same parameter indicate statistically significant differences according to the $t$-test $(p<0.05)$. The data are expressed as means \pm SE $(n=20)$.

\subsection{Effect of Zn Deficiency on Grain Yield Components of Plants}

Between all variants, only $T$. dicoccoides, containing a functional allele of the Gpc$B 1$ gene, demonstrated an increase in the spike DW under Zn deficiency (Table 2). Zn deficiency did not affect the spike length and DW in the introgressive lines. Moreover, the wheat cv. Festivalnaya had no statical significant differences in the spike length and DW, although a tendency towards a decrease in spike length may be suggested.

Table 2. The effect of Zn deficiency on the spike length and DW of wheat with different allelic statuses of the Gpc-B1 gene. Averages followed by different letters within the same parameter indicate statistically significant differences according to the $t$-test $(p<0.05)$. The data are expressed as means \pm SE $(n=20)$.

\begin{tabular}{ccccc}
\hline \multirow{2}{*}{ Variant } & \multicolumn{2}{c}{ Spike Length $(\mathbf{c m})$} & \multicolumn{2}{c}{ Spike DW (g) } \\
\cline { 2 - 5 } & Zn+ & Zn- & Zn+ & Zn- \\
\hline Triticum dicoccoides & $4.38 \pm 0.14 \mathrm{c}$ & $4.59 \pm 0.13 \mathrm{c}$ & $0.45 \pm 0.02 \mathrm{c}$ & $0.53 \pm 0.02 \mathrm{~b}$ \\
Triticum aestivum & $7.08 \pm 0.22 \mathrm{~b}$ & $6.67 \pm 0.11 \mathrm{~b}$ & $1.01 \pm 0.10 \mathrm{a}$ & $1.20 \pm 0.10 \mathrm{a}$ \\
cv. Festivalnaya & $8.20 \pm 0.32 \mathrm{a}$ & $8.41 \pm 0.29 \mathrm{a}$ & $1.01 \pm 0.10 \mathrm{a}$ & $1.18 \pm 0.11 \mathrm{a}$ \\
Line 15-7-1 & $8.21 \pm 0.19 \mathrm{a}$ & $7.99 \pm 0.18 \mathrm{a}$ & $1.33 \pm 0.08 \mathrm{a}$ & $1.42 \pm 0.08 \mathrm{a}$ \\
Line 15-7-2 & & &
\end{tabular}

The changes in grain number and grain yield per spike also did not depend on the allele status of the Gpc-B1 gene in wheat under Zn deficiency. Among the studied variants, only $T$. dicoccoides showed an increase in grain number and grain yield per spike under $\mathrm{Zn}$ deficiency compared to the control (Table 3). 
Table 3. The effect of $\mathrm{Zn}$ deficiency on grain number and grain yield per spike in wheat with different allelic statuses of the $G p c-B 1$ gene. Averages followed by different letters within the same parameter indicate statistically significant differences according to the $t$-test $(p<0.05)$. The data are expressed as means \pm SE $(n=20)$.

\begin{tabular}{ccccc}
\hline \multirow{2}{*}{ Variant } & \multicolumn{2}{c}{$\begin{array}{c}\text { Grain Number, } \\
\text { Pieces per Spike }\end{array}$} & \multicolumn{2}{c}{$\begin{array}{c}\text { Grain Yield, } \\
\text { g per Spike }\end{array}$} \\
\cline { 2 - 5 } & Zn+ & Zn- & Zn+ & Zn- \\
\hline Triticum dicoccoides & $12.84 \pm 0.87 \mathrm{~d}$ & $14.30 \pm 0.65 \mathrm{c}$ & $0.29 \pm 0.02 \mathrm{e}$ & $0.37 \pm 0.02 \mathrm{~d}$ \\
Triticum aestivum & $20.63 \pm 2.47 \mathrm{~b}$ & $20.75 \pm 1.92 \mathrm{~b}$ & $0.68 \pm 0.09 \mathrm{c}$ & $0.91 \pm 0.09 \mathrm{abc}$ \\
cv. Festivalnaya & $21.20 \pm 2.23 \mathrm{~b}$ & $21.10 \pm 2.08 \mathrm{~b}$ & $0.76 \pm 0.09 \mathrm{bc}$ & $1.01 \pm 0.09 \mathrm{ab}$ \\
Line 15-7-1 & $27.79 \pm 1.23 \mathrm{a}$ & $26.20 \pm 1.28 \mathrm{a}$ & $0.96 \pm 0.06 \mathrm{ab}$ & $1.07 \pm 0.06 \mathrm{a}$ \\
Line 15-7-2 & & &
\end{tabular}

\subsection{Effect of Zn Deficiency on Grain Zn Content}

$Z n$ deficiency affected the $Z n$ accumulation in the grains differently between wheat with a functional and a non-functional allele of the Gpc-B1 gene. The plants with a functional allele of the Gpc-B1 gene (T. dicoccoides and line 15-7-1) under Zn deficiency accumulated more $\mathrm{Zn}$ in their grains than the control plants (Figure 2). T. aestivum cv. Festivalnaya with a non-functional allele of the Gpc-B1 gene under Zn deficiency had a lower Zn concentration its grains compared to the control, whereas line 15-7-2 had no difference in $\mathrm{Zn}$ concentration. According the results, the wheat with a functional Gpc-B1 gene allele had a higher $\mathrm{Zn}$ content in its grains than the plants with a non-functional allele of $G p c-B 1$ gene under $\mathrm{Zn}$ deficiency conditions.

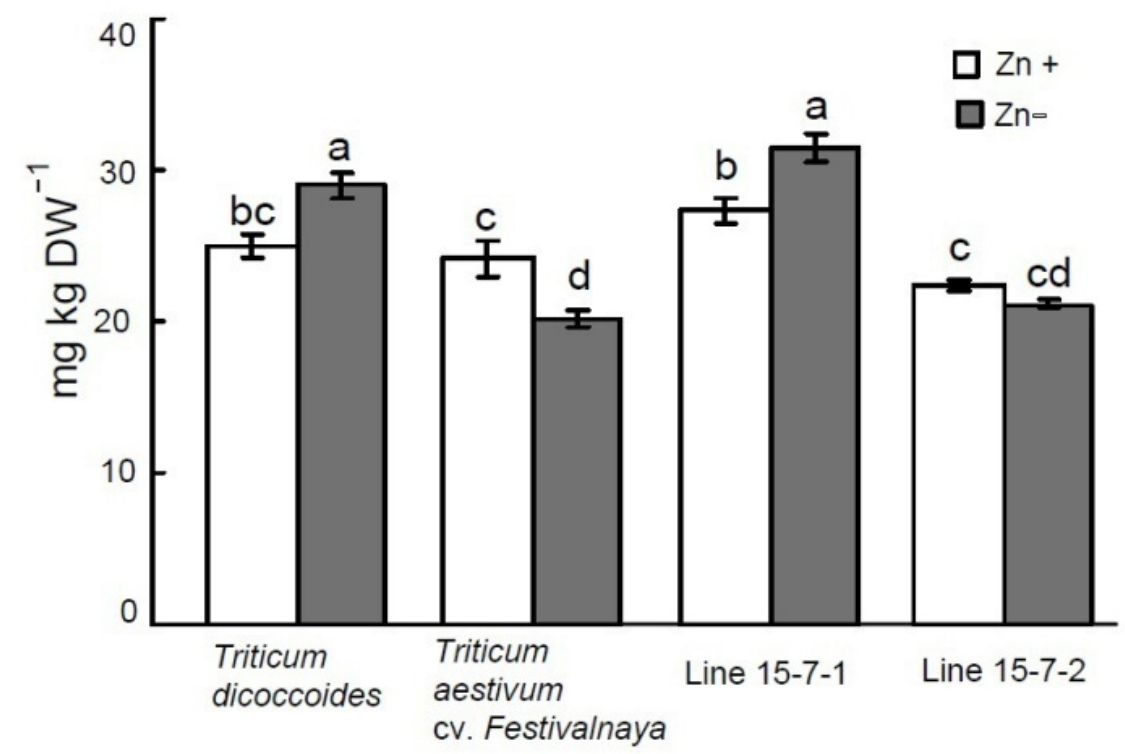

Figure 2. The effect of Zn deficiency on Zn concentration in grains of wheat with different allele statuses of the $G p c-B 1$ gene. Averages followed by different letters within the same parameter indicate statistically significant differences according to the $t$-test $(p<0.05)$. The data are expressed as means \pm SE $(n=3)$.

\section{Discussion}

The Gpc-B1 gene encodes a NAC (domain present in NAM, ATAF, and CUC genes) transcription factor. NAC proteins are plant-specific transcription factors that have been shown to function in relation to plant development, as well as abiotic and/or biotic stress responses [31-33]. The main motivation for the introgression of the wild-type Gpc-B1 allele into a modern wheat cultivars is to improve its grain nutritional content [34]. Lines with a functional allele of the $G p c-B 1$ gene are capable of accumulating more trace elements 
including $\mathrm{Zn}$ in grains as compared to lines containing a non-functional allele. This is linked to their high capacity for remobilization of the microelements and their transport from the leaves to the spike during grain filling [35]. However, the response of plants with different functional statuses of the Gpc-B1 gene allele under Zn deficiency is poorly understood.

Zn deficiency in substrates leads to a decrease in the growth of cereals and their aboveand underground biomass [36-38]. Primarily, this is more visible for species (varieties, genotypes) that are less tolerant to Zn deficiency. In our experiments, the height and FW of all of the wheat plants did not differ under the optimal or deficient $\mathrm{Zn}$ contents in the substrate. However, T. dicoccoides experienced an increase in flag leaf area under $\mathrm{Zn}$ deficiency. Considering that the flag leaf is the main donor of assimilates for grain formation in cereals, the increase in its area can result in an enhancement of grain production under micronutrients deficiency.

$\mathrm{Zn}$ deficiency in substrates causes a decrease in the $\mathrm{Zn}$ concentration in grains and can affect the grain yield. Previously, it was demonstrated that these conditions also resulted in a decrease in spike size, grain quantity in spikes, number of unsterile spikelets, and grain weight. In particular, Zn deficiency led to an almost two-folddecrease in grains per cob in a hybrid variety of maize, namely, Pioneer-32 [39]. Moreover, the maize variety Xun County showed a decrease in the length of its cobs and the weight of 1000 seeds [40]. Zn deficiency caused a decrease in grain weight and quantity per spike in the wheat variety Yumai 49-198 compared to plants under optimal Zn nutrition [41]. These changes could be a consequence of the negative effect of $\mathrm{Zn}$ deficiency on the processes of flower formation, pollination, and fertilization, and/or the interruption of physiological, and biochemical processes in mother plants [42-45].

Some researchers demonstrated that plants with different grain protein contents (GPCs) and allele statuses of the Gpc-B1 gene under sufficient trace element nutrition experienced no differences in grain yield. In particular, high and low GPC inbred lines of hard red spring wheat (ND683/'Bergen', 'Glupro' /'Keene', and 'Glupro' /'Bergen') [46] experienced no differences in yield, although there were differences in the 1000-grain weight [47]. In the same species of wheat, Carter et al. (2012) also demonstrated the absence of a difference in grain yield between isogenies lines with a non-functional or functional allele of the Gpc-B1 gene [48]. Nadolska-Orczyk et al. (2017) found that, under Zn deficiency, wheat with a non-functional allele of $G p c-B 1$ gene had increased grain size but a delayed aging process [49]. The authors supposed that these changes could be a result of a long ripening time. In our experiment, wheat plants with different allele statuses of the Gpc-B1 gene did not experience a significant decrease in the length and DW of the spike under Zn deficiency. Only T. dicoccoides demonstrated an increase in the spike DW under these conditions.

As described above, the low content of $\mathrm{Zn}$ in wheat grains is a crucial global problem. The use of the method of distant hybridization with the introduction of a functional allele of the $G p c-B 1$ gene from wild wheat aims to eliminate this problem. Particularly, Distelfeld et al. (2007) showed that the recombinant lines containing a functional allele of the $G p c-B 1$ gene accumulated more $\mathrm{Zn}$ than lines with a non-functional allele of the $G p c-B 1$ gene [35]. Winter wheat with the introgressing Gpc-B1 gene from T. dicoccoides has a significantly higher amount of $\mathrm{Zn}$ in the grains [28]. Our results demonstrated that under Zn deficiency the wheat plants with a functional Gpc-B1 gene allele (T. dicoccoides and line 15-7-1) accumulated more $\mathrm{Zn}$ in their grains than plants with a non-functional allele of the $G p c-B 1$ gene. We must then consider that our study takes into consideration only some varieties of cultivated wheat. It would therefore be useful to extend the study to other wheat varieties, preferably ancient ones, to better evaluate the results obtained in the present study.

\section{Conclusions}

According to our data, the wheat response to $\mathrm{Zn}$ deficiency does not depend on the occurrence of a functional allele of the $G p c-B 1$ gene. However, the $\mathrm{Zn}$ concentration in the 
grains was higher in the wheat with a functional allele of the Gpc-B1 gene in comparison to the wheat carrying a non-functional allele of the $G p c-B 1$ gene. We suppose that the realization of the distant hybridization method for the creation of wheat lines with a functional allele of the Gpc-B1 gene could be a solution for eliminating Zn deficiency in nutrition due to their ability to accumulate higher amounts of $\mathrm{Zn}$ in grains without a decrease in yield, even under Zn deficiency in substrates. However, further research is needed to assess the potential for wheat with a functional allele of the Gpc-B1 gene growing under Zn deficiency. Furthermore, research is still required with the aim of evaluating the capability of other introgressive lines with a functional and non-functional allele of the $G p c-B 1$ gene to accumulate the $\mathrm{Zn}$ in a higher amount in grains under Zn deficiency in substrate. The mechanisms of these phenomena also need to be studied.

Author Contributions: Conceptualization, N.K. and N.D.; Methodology, N.K., N.D. and Y.B.; data curation, N.K., Y.B., A.I. and O.O.; validation, N.K., N.D., Y.B. and O.O., Statistical analyses, N.R. and A.I.; Writing—original draft preparation, N.D., N.K., N.R. and Y.B.; Writing—review and editing, N.R. and N.K. All authors have read and agreed to the published version of the manuscript.

Funding: This study was financially supported by the Russian Foundation for Basic Research (RFBR) (Project No. 20-516-00016) and the Belarusian Republican Foundation for Fundamental Research (BRFBR) (Project No. B20P-240). This paper was written as part of a state order (No. 0218-2019-0074).

Institutional Review Board Statement: Not applicable.

Informed Consent Statement: Not applicable.

Data Availability Statement: The data are contained within the article.

Conflicts of Interest: The authors declare no conflict of interest.

\section{References}

1. Sinclair, S.A.; Krämer, U. The zinc homeostasis network of land plants. Biochem. Biophys. Acta 2012, 1823, 1553-1567. [CrossRef] [PubMed]

2. Zhang, Y.; Gladyshev, V.N. Comparative genomics of trace element dependence in biology. J. Biol. Chem. 2011, 286, 23623-23629. [CrossRef] [PubMed]

3. Wani, A.L.; Parveen, N.; Ansari, M.O.; Ahmad, M.F.; Jameel, S.; Shadab, G.G.H.A. Zinc: An element of extensive medical importance. Cur. Med. Res. Prac. 2017, 7, 90-98. [CrossRef]

4. Alloway, B.J. Zinc in Soils and Crop Nutrition, 2nd ed.; IZA: Brussels, Belgium; IFA: Paris, France, 2008 ; Volume 137.

5. Ricachenevsky, F.K.; Menguer, P.K.; Sperotto, R.A.; Fett, J.P. Got to hide your Zn away: Molecular control of Zn accumulation and biotechnological applications. Plant Sci. 2015, 236, 1-17. [CrossRef]

6. Maret, W. The redox biology of redox-inert zinc ions. Free Radic. Biol. Med. 2019, 134, 311-326. [CrossRef]

7. Hafeez, B.; Khanif, Y.M.; Saleem, M. Role of zinc in plant nutrition-A review. Am. J. Exp. Agricul. 2013, 3, 374-391. [CrossRef]

8. Sadeghzadeh, B. A review of zinc nutrition and plant breeding. J. Soil Sci. Plant Nutri. 2013, 13, 905-927. [CrossRef]

9. Gupta, N.; Ram, H.; Kumar, B. Mechanism of zinc absorption in plants: Uptake, transport, translocation and accumulation. Rev. Environ. Sci. Biotechnol. 2016, 15, 89-109. [CrossRef]

10. Broadley, M.R.; White, P.J.; Hammond, J.P.; Zelko, I.; Lux, A. Zinc in plants. New Phytol. 2007, 173, 677-702. [CrossRef]

11. Liuzzi, J.P.; Pazos, R. Interplay between autophagy and zinc. J. Trace Elem. Med. Biol. 2020, 62, 126636. [CrossRef]

12. Bonaventura, P.; Benedetti, G.; Albarède, F.; Miossec, P. Zinc and its role in immunity and inflammation. Autoimmun. Rev. 2015, 14, 277-285. [CrossRef] [PubMed]

13. Brown, K.H.; Wuehler, S.E.; Peerson, J.M. The importance of zinc in human nutrition and estimation of the global prevalence of zinc deficiency. Food Nuti. Bull. 2001, 22, 113-125. [CrossRef]

14. Gregory, P.J.; Wahbi, A.; Adu-Gyamfi, J.; Heiling, M.; Gruber, R.; Joy, E.J.M.; Broadley, M.R. Approaches to reduce zinc and iron deficits in food systems. Theor. Appl. Genet. 2017, 130, 1081-1098. [CrossRef]

15. Suzuki, M.; Suzuki, T.; Watanabe, M.; Hatakeyama, S.; Kimura, S.; Nakazono, A.; Honma, A.; Nakamaru, Y.; Vreugde, S.; Homma, A. Role of intracellular zinc in molecular and cellular function in allergic inflammatory diseases. Allergol. Intern. 2020, 70, 190-200. [CrossRef]

16. Nriagu, J. Zinc Deficiency in Human Health. Encyclopedia of Environmental Health, 2nd ed.; Elsevier Inc.: Amsterdam, The Netherlands, 2018. [CrossRef]

17. Noulas, C.; Tziouvalekas, M.; Karyotis, T. Zinc in soils, water and food crops. J. Trace Elem. Med.Biol. 2018, 49, 252-260. [CrossRef]

18. Prasad, A.S. Discovery of zinc for human health and biomarkers of zinc deficiency. In Molecular, Genetic, and Nutritional Aspects of Major and Trace Minerals; Collins, J.F., Ed.; Academic Press: Cambridge, MA, USA, 2017; pp. 241-260. 
19. FAO. 2013. The State of Food and Agriculture. Food Systems for Better Nutrition. 2013. Rome. Available online: www.fao.org/3/ i3300e/i3300e.pdf (accessed on 15 April 2021).

20. FAO. Crop Prospects and Food Situation-Quarterly Global Report No. 1; FAO: Rome, Italy, 2021. [CrossRef]

21. Rawat, N.; Tiwari, V.K.; Singh, N.; Randhawa, G.S.; Singh, K.; Chhuneja, P.; Dhaliwal, H.S. Evalution and utilization of Aegilops and wild Triticum species for enhancing iron and zinc content in wheat. Gen. Resour. Crop Evol. 2009, 56, 53-64. [CrossRef]

22. Perrino, E.V.; Wagensommer, R.P. Crop Wild Relatives (CWR) Priority in Italy: Distribution, Ecology, In Situ and Ex Situ Conversation and Expected Actions. Sustainability 2021, 13, 1682. [CrossRef]

23. Zhang, W.; Xue, Y.-F.; Chen, X.-P.; Zhang, F.-S.; Zou, C.-Q. Zinc nutrition for high productivity and human health in intensive production of wheat. Adv. Agron. 2020, 163, 179-217.

24. Velu, G.; Ortiz-Monasterio, I.; Cakmak, I.; Hao, Y.; Singh, R.P. Biofortification strategies to increase grain zinc and iron concentrations in wheat. J. Cereal Sci. 2014, 59, 365-372. [CrossRef]

25. Uauy, C.; Distelfeld, A.; Fahima, T.; Blechl, A.; Dubcovsky, J.A. NAC gene regulating senescence improves grain protein, zinc and irons content in wheat. Science 2006, 314, 1133649. [CrossRef]

26. Avni, R.; Zhao, R.; Pearce, S.; Jun, Y.; Uauy, C.; Tabbita, F.; Fahima, T.; Slade, A.; Dubcovsky, J.; Distelfeld, A. Functional characterization of GPC-1 genes in hexaploid wheat. Planta 2014, 239, 313-324. [CrossRef] [PubMed]

27. Brevis, J.C.; Dubcovsky, J. Effects of the chromosome region including the Gpc-B1 locus on wheat grain and protein yield. Crop Sci. 2010, 50, 93-104. [CrossRef]

28. Pokhylko, S.Y.; Schwartau, V.V.; Mykhalska, L.M. ICP-MS analysis of bread wheat carrying the GPC-B1 gene of Triticumturgidum ssp. Dicoccoides. Biotech. Acta 2016, 9, 64-69. [CrossRef]

29. Vishwakarma, M.K.; Mishra, V.K.; Gupta, P.K.; Yadav, P.S. Integression of the high grain protein gene Gpc-B1 in a elite wheat variety of Indo-Gangetic Plains through marker assisted backcross breeding. Cur. Plant Biol. 2014, 1, 60-67. [CrossRef]

30. Anikiev, V.V.; Kutuzov, F.F. A new method for determining the leaf surface of cereals. Rus. J. Plant Phys. 1961, 8, 375-378. (In Russian)

31. Nakashima, K.; Takasaki, H.; Mizoi, J.; Shinozaki, K.; Yamaguchi-Shinozaki, K. NAC transcription factors in plant abiotic stress responses. Biochim. Biophys. Acta 2012, 1819, 97-103. [CrossRef]

32. Yoon, Y.; Seo, D.H.; Shin, H.; Kim, H.J.; Kim, C.M.; Jang, G. The role of stress-responsive transcription factors in modulating abiotic stress tolerance in plants. Agronomy 2020, 10, 788. [CrossRef]

33. Shao, H.; Wang, H.; Tang, X. NAC transcription factors in plant multiple abiotic stress responses: Progress and prospects. Fron. Plant Sci. 2015, 6. [CrossRef]

34. Tabbita, F.; Pearce, S.; Barneix, A.J. Breeding for increased grain protein and micronutrient content in wheat: Ten years of the GPC-B1 gene. J. Cereal Sci. 2017, 73, 183-191. [CrossRef]

35. Distelfeld, A.; Cakmak, I.; Peleg, Z.; Öztürk, L.; Yazici, A.M.; Budak, H.; Saranga, Y.; Fahima, T. Multiple QTL-effects of wheat Gpc-B1 locus on grain protein and micronutrient concentrations. Physiol. Plant. 2007, 129, 635-643. [CrossRef]

36. Cakmak, I.; Torun, B.; Erenoğlu, B.; Öztürk, L.; Marschner, H.; Kalayci, M.; Ekiz, H.; Yilmaz, A. Morphological and physiological differences in the response of cereals to zinc deficiency. Euphytica 1998, 100, 349-357. [CrossRef]

37. Wissuwa, M.; Ismail, A.M.; Yanagihara, S. Effects of zinc deficiency on rise growth and genetic factors contributing to tolerance. Plant Physiol. 2006, 142, 731-741. [CrossRef] [PubMed]

38. Kabir, A.H.; Hossain, M.M.; Khatun, M.A.; Sarcar, M.R.; Haider, S.A. Biochemical and molecular mechanisms associated with Zn deficiency tolerance and signaling in rice (Oryza sativa L.). J. Plant. Interac. 2017, 12, 447-456. [CrossRef]

39. Ehsanullah; Tariq, A.; Randhawa, M.A.; Anjum, S.A.; Nadeem, M.; Naeem, M. Exploring the role of zinc in maize (Zea mays L.) through soil and foliar application. Univers. J. Agricul. Res. 2015, 3, 69-75. [CrossRef]

40. Liu, H.; Gan, W.; Rengel, Z. Zn fertilization and water stress affects plant water relations, stomatal conductance and osmotic adjustment in chickpea (Cicer arientinum L.). J. Soil Sci. Plant Nutr. 2016, 16, 550-662.

41. Khattak, S.G.; Dominy, P.J.; Ahmad, W. Effect of Zn as soil addition and foliar application on yield and protein content of wheat in alkaline soil. J. Nation. Sci. Found. Sri Lanka 2015, 43, 303-312. [CrossRef]

42. Marschner, H. Mineral Nutrition of Higher Plants, 2nd ed.; Academic Press: Amsterdam, The Netherlands, 1995; pp. 184-200. [CrossRef]

43. Pandey, N.; Pathak, G.; Sharma, C.P. Zinc is critically required for pollen function and fertilization in lentil. J. Trace Elem. Med. Biol. 2006, 20, 89-96. [CrossRef]

44. Pandey, N.; Pathak, G.C.; Singh, A.K. Differential sensitivity of maize to zinc and high light intensity. Plant Stress 2010, 4, 18-24.

45. Mousavi, S.R. Zinc in crop production and interaction with phosphorus. Aust. J. Basic Appl. Sci. 2011, 5, $1503-1509$.

46. Mesfin, A.; Frohberg, R.; Anderson, J.A. RFLP markers associated with high grain protein from Triticum turgidum L. var. dicoccoides introgressed into hard red spring wheat. Crop Sci. 1999, 39, 508-513. [CrossRef]

47. Brevis, J.C.; Morris, C.F.; Manthey, F.; Dubcovsky, J. Effect of grain protein content locus Gpc-B1 on bread and pasta quality. J. Cereal Sci. 2010, 51, 357-365. [CrossRef]

48. Carter, A.H.; Santra, D.K.; Kidwell, K.K. Assessment of the effects of the Gpc-B1 allele on senescence rate, grain protein concentration and mineral content in hard red spring wheat (Triticum aestivum L.) from the Pacific Northwest Region of the USA. Plant Breed. 2012, 131, 62-68. [CrossRef]

49. Nadolska-Orczyk, A.; Rajchel, I.K.; Orczyk, W.; Gasparis, S. Major genes determining yield-related traits in wheat and barley. Global Food Sec. 2017, 15, 1-10. [CrossRef] [PubMed] 